УДК $78.01+785 / .789$

\title{
А. Черноіваненко
}

\section{ПОНЯТТЯ «АБСОЛЮТНА МУЗИКА» У РОЗВИТКУ МУЗИЧНОГО ІНСТРУМЕНТАЛІЗМУ}

У статті аналізуються понятійно-категоріальне поле терміну «абсолютна музика» у розвитку академічного музичного інструменталізму та його роль в історії та теорії музики. Наголошується значення поняття у затвердженні на теоретичному і практичному рівнях уявлення про інструментальну парадигму музики зі спиранням на гіпотезу I. Земцовського про полігенезис музики. Виявляються співвідношення понять «абсолютної》, «автономної», «інструментальної», «академічної», «прикладної, «програмної» музики.

Ключові слова: «абсолютна музика», автономна музика, музичний інструменталізм, інструментальна музика, філософія музики.

Сила «абсолютної музики» така, що «музика залишається самодостатньою й без усякого слова», - затверджує В. Холопова [19, с. 192], використовуючи німецький термін XIX століття, не сприйнятий у вітчизняному музикознавстві (слов'янська музична думка віддавала перевагу вираженню «чиста, безпрограмна інструментальна музика»). Однак саме поняття «абсолютної музики» свого часу підняло симфонію бетховенського типу на вищий щабель музичної й художньої ієрархії, затвердивши тезу про те, що власне інструментальна культура є музикою як такою (нагадаємо, що диференціація вже автономної якості музики на вокальну й інструментальну відбивається в народній термінології як опозиція «музика - спів»: «музикою» у народі називають інструментальне музикування [11, с. 92]). Але за твердженням В. Холопової, парадигма абсолютної музики «продовжує діяти й понині» [19, с. 29], а «здане до архіву» поняття, на думку Т. Чередниченко, «не скасовує проблеми збігу конкретної музичної творчості із сутнісною повнотою можливостей мистецтва звуків» [1, c. 13]. Неактуальність даної проблеми в сьогоднішній культурній ситуації «рівнозначна ії актуальності - як історичної «точки відліку» для розуміння сучасності» [1, с. 13]. Саме тому виникає необхідність поняттєво-змістовного, естетико-історичного, музикознавчого аналізу поняття «абсолютна музика», виявлення його значення в розвитку академічної інструментальної музичної культури й розуміння місця цієї останньої в культурі й мистецтві. Перераховані позиції становлять актуальність і мету даної статті.

(C) Черноіваненко А., 2014 
Обгрунтування й визнання автономності «чистої», «абсолютної» - інструментальної музики формувалося теоретиками мистецтва від XVIII століття, чому передував досить довгий період становлення незалежного статусу музики як самостійного мистецтва - у її різних видових категоріях. Власне дослідження суті й дифінування поняття «музика» залишається відкритим процесом у роботі теоретиків різних гуманітарних сфер - музикознавства, філософії, естетики, культурології, соціології й навіть медицини - і сьогодні. Так, В. Холопова присвятила такому дослідженню понад 25 років [19]. Варто відзначити й активізацію дисертаційних досліджень питання в області філософських наук в останні десятиліття, що виступає цілком аргументованим як з урахуванням античної «генетики» ставлення до музики, так і через висоту, значушість і складності музичних ідей. Останні сьогодні очевидно виявляють споріднення концептуальності філософського мислення.

Відомо, що у своїй філософській системі Гегель розглядає послідовний ряд розвитку різних щаблів людської свідомості: від нижчої форми (безпосереднього почуттєвого сприйняття) - до вищої (абсолютного, або чистого, знання), де зовнішні предмети повністю переборені й дух мислить тільки власну сутність. Абсолютний дух, у свою чергу, проходить три щаблі розвитку - мистецтво, релігію й філософію. При цьому мистецтво, за Гегелем, - це «безпосередня форма знання абсолютної ідеї (курсив наш. - А. Ч.)» [20, с. 56], релігія своїм джерелом одкровення має Бога, філософія - це вищий щабель розвитку абсолютного духу, «повне розкриття істини, що втримується в мистецтві й релігії. У філософії ідея пізнає саму себе, вона піднімається до свого «чистого принципу», з'єднує кінець абсолютної ідеї з їі початком» [20, с. 56]. Якщо, за Гегелем, філософія - це світ, «схоплений думкою», а сам світ є абсолютною ідеєю, то відбувається «бажана завершеність» розвитку абсолютної ідеї [5, с. 394]. Однак, за слушною вказівкою В. Холопової, вже після смерті великого філософа музика підніметься до обох більш високих (ніж мистецтво) гегелівських щаблів Абсолютного духу: їі роль у суспільстві й свідомості почнуть порівнювати з релігією й філософією (що спостерігалося вже в Давній Греції, але інакше - музика вважалася не тільки й не стільки мистецтвом, скільки наукою, засобом виховання, терапії й керування, тобто виходила за рамки мистецтва [9]). Власне, музикознавці кінця XX - початку XXI століть оголосять концептуалізм не просто своїм предметом, але ідейною основою музики [17, с. 28-30]. Більше 
того, доведені до досконалості протягом XVII - XX століть «емоційні можливості й найвищий логічний взаємозв'язок усіх елементів музики» (В. Холопова) дозволили цьому виду мистецтва передавати своєю «безсловесною мовою» навіть те, «що неможливо було висловити у вигляді філософських ідей» [19, с. 23]. Очевидним провідником і основоположником цього концептуально-філософсько-музичного шляху - шляху чистого безпрограмного, невербального інструменталізму став Бетховен (О. Лосєв затверджує, що «у Бетховена немає «бога», у нього $є$ Бог» [10]), шо породило бетховеноцентризм подальшої музичної думки» [19, с. 98]. Тим часом, емансипація музики фактично відбулася в епоху Й. С. Баха, $\mathrm{i}$ «не стала тут помітною, оскільки Бах оточував іï̈ «завісою словесних емблем» [19, с. 98]. Однак твердження «нового мистецтва звуків у точному сенсі слова» (Г. Берліоз) було б неможливо без триваючої протягом усієї творчості віденського класицизму канонізації музичної мови, жанрів, форм, інструментального складу симфонічного оркестру й струнного квартету, мажоро-мінорної системи, індивідуальності й неповторності музичного твору, композитора й виконавця, свободи (музики й музиканта) від ритуально-обрядової залежності. Власне «апріорно евристичний» характер музичного бароко, що характеризується, насамперед, «виникненням опери, становленням інструментального концерту, появою концертних залів, внесенням нечуваної сили афектів енергією, що ніколи не існувала раніше, моторного руху» привів до історично нового поняття «музика». Перераховані найбільші відкриття мистецтва у значній мірі сформувалися в інструментальній («абсолютній») музиці (включаючи вплив розвиненого музичного інструменталізму на оперу). Це нове поняття музики від епохи бароко стає виразником нового шляху музики.

В епоху романтизму «музичне» осмислюється як повноправна філософська категорія; музика синонімізується зі справжньою художністю, стає еталоном домірності й спряженості форм, гармонійної цілісності й завершеності художніх творів (Лосєв у різних своїх роботах, неодноразово й послідовно, проводить думку про музику як найкращу 3 моделей діалектичного становлення). Саме у цю епоху стверджується поняття «абсолютної музики». Слід зазначити, що на формування світу ідей про музику в культурі XIX ст. істотний вплив справили філософські ідеї Ф. Шеллінга, у яких музика усвідомлюється як ритм прототипів природи й власне універсуму, а також А. Шопенгауера, який усьому світу давав міфологічне тлумачення, інтерпретуючи його як 
музичний твір, а музику - як засіб осмислення цього світу, що має можливість у загальних формах виразити те, що інші форми духу виражають як частини [22]. Зазначені філософські парадигми яскравіше всього виявилися в інструментальних формах абсолютної, «чистої» музики. Схожі позиції виявляв і Ф. Ніцше: «Найбільш зрозумілим у мові $є$ не слово, а тон, сила, модуляція, темп... - коротше, музика за словом... наразі все те, що не може бути написане» [15, с. 751].

Філософська думка ХХ століття поглиблювала філософські паралелі музики, яка за О. Лосєвим, відрізняється від чистої думки відсутністю пізнавальної оформленості, але дає чисту якість, обертає нас до самої сутності миру. Думка О. Лосєва про те, що «музика напружується до слова, до Логосу», - саме про Логос, про «ту вищу субстанціональність, до якої завжди спрямована велика музика - будь то міфологічний Хаос або ж Логос Нового Завіту» [10, с. 606]. Розрізняючи в плані піднесення («восторжения») людського духу три стани - повсякденну реальність життя занепалої людини (його «практичне існування»), мистецтво й молитву в подвигу «умного делания», О. Лосєв відзначає, що «із усіх мистецтв одна лише музика наближається за значенням до розумної молитви», i «вище музики - тільки молитва» [10, с. 908]. Принципова формула Лосєва: художня форма є особистість як символ, або символ як особистість - говорить про сутність вираження, пов'язаного з «досвідом абсолютної Особистості». 3 іншого боку, у своїй спрямованості до людини музика несе два основні світовідчуття, що існують як протилежності, умовно порівнювані зі «спогляданням» і «дією». Музичне й релігійне зближає ціннісне естетичне переживання: відчуття прекрасного й піднесеного. Мова йде в Лосєва про захват, екстаз, викликаний музично-естетичним буттям, що сплітаються з релігійним світоглядом, світовідчуттям любові й природи, абсолютними цінностями

Адже метафізичний простір, яким обдаровує нас музика, має глибоку основу, що повертає нас до першооснов людського буття. Музика, яка, здавалося б, явно протистоїть за своєю природою «раціональності» на користь «вимислу», насправді підтверджує самим фактом свого існування й багатовікового розвитку можливість насиченого філософічного відношення з виходом на Абсолют. Наприкінці XX початку XXI століть сама музика стає підставою для філософських суджень і висновків [12; 19 та ін.]. Подібне з'єднання становить сутність музичної філософії Т. Адорно, який «перевіряє філософію мистецтвом» (а не навпаки), тому що «сугубо конкретний досвід слухання 
й зрозуміння музики викликає філософське тлумачення й філософські висновки» [12, с. 291]. На «обмін місцями» музики й філософії сьогодні вказує й В. Холопова [19, с. 35].

Таким чином, у ході розвитку «абсолютної музики», в гегелівській тріаді «теза - антитезис - синтез» (яка робить його філософську систему строгою, чіткою, що дозволяє показати поступальний характер розвитку світу) сьогодні відбувається діалектична заміна, тобто «бажана завершеність» розвитку абсолютної ідеї тепер відбувається саме в музиці.

Прийнято вважати, що самий термін «абсолютна музика» уперше використовується Р. Вагнером (1846) у його «Програмі» до Дев'ятої симфонії Бетховена у значенні «вищих виразних можливостей самостійного мистецтва звуків» [1, с. 12]. Однак В. Холопова, слідом за К. Дальхаузом - автором книги «Ідея абсолютної музики» (1978), стверджує, шо поняття сформувалося в романтичній музичній естетиці ще близько 1800 року, насамперед у судженнях трьох письменників - В. Вакенродера («Вчення про душу сьогоднішньої інструментальної музики»), Л. Тіка (стаття «Симфонія») і В. Гофмана (рецензія на П'яту симфонію Бетховена) [19, с. 26]. Ці автори під «абсолютною» розуміли «власне музику», «музику як таку», «чисто інструментальну, вільну від словесного тексту, функціонального призначення й емпірично сприйманих афектів» [19, с. 26] (останне, втім, сильно суперечило високому емоційному розжаренню романтизму й тому, очевидно, викликало активне неприйняття російської школи XIX століття з її «стихією музичною» (Б. Асафьєв), і «здивувало» В. Холопову на початку століття XXI).

Адже ключовою ідеєю «абсолютної музики» виступила емансипація музичного інструменталізму і пов'язана з його природою й можливостями безпосередності вираження Абсолюту. Слід зазначити, що сам процес зазначеної емансипації розпочався сторіччям раніше. Він обчислюється від початку XVII століття і протікав досить складно й не завжди рівно. Впритул же до XVII століття інструментальна музика носила прикладне функціональне значення й підкорялася більш «важливій і високій» - вокальній. У XVII столітті навіть в умовах розпочатої автономізації довгий час існувала традиція проекції вокальної музики на інструментальну як у питаннях звуко- і темоутворення, так і у галузі риторики (у вокальному мистецтві цей зв'язок логічно обумовлювався наявністю слова). Втім, вже у XVIII столітті відомі спроби встановити паралелі між риторикою та інструментальною 
виконавською й композиторською практикою. Зокрема, М. Пилаєв приводить висловлення французького клавесиніста де Сен-Ламбера, котрий опублікував два музичних трактати, у яких одержала відбиття й риторична проблематика клавесинового інструменталізму [16, с. 67]. Так, Сен-Ламбер вказує, що скоріше «зразки красномовства схожі на музичну п'єсу, тому що гармонія, ритм, такт, розмір та інші подібні речі, котрих дотримується вправний оратор у складанні своїх творів, належать більш музиці, ніж риториці» [16, с. 67].

Німець Маттезон, за міркуванням К. Дальхауза, фактично висуває тезу про естетичне право інструментальної музики на власний статус i називає це «звуковою мовою» (Klangrede) (цит. за: [16, с. 13]). На риторичну проблематику спеціально звертали увагу I. Форкель, Г. Кох, ін., а сама риторика відіграла, безумовно, найважливішу роль у становленні й розвитку форм інструментальної музики (хоча Дальхауз, що визнавав важливість категорій ораторської мови для музики, застерігав від надмірно прямолінійних аналогій). Естетична наука XVIII ст. розглядає інструментальну музику, що вже виділилася на практиці на той час, у контексті теорії «подвійного мімезису» (подвійного наслідування»): вокальна музика наслідує «природу», інструментальна вокальну. Багато дослідників (у тому числі сучасних) вважають, що інструментальна музика має більш пізнє в порівнянні з вокальною походження [23]. Інші (наприклад, І. Мацієвський [11], О. Неустроєв [14], I. Земцовський [7], ін.), визнаючи первісний нерозривний зв'язок з вокалом, стверджують, що інструментальне музикування, споконвічно пов'язане з життєво необхідними процесами, а також ритуальними обрядами із прихованням людського голосу, робить інструменти й інструменталізм певними «знаковими носіями». А у такій знаковості - «позавербальна трансляційна система» спрацьовує й за «межами власне трудового досвіду» [11, с. 7] і ритуальних дій. Гіпотеза, згідно з якою походження музичних інструментів не пов'язане 3 вокальною музикою і могло навіть передувати ӥй, висловлювалася вже багато років тому [14]. Визрівання музики «з немузики» I. Земцовський вбачає «не тільки як «механічний» процес вичленуваннявиділення музичного інструменту», але і як становлення нової якості: «Можна стверджувати, що історично музичний інструмент - це... якийсь новий, взаємоперехідний синтез, якесь нове, небуденне мислення, нарешті» [7, с. 127].

На рубежі XVIII-XIX століть музика остаточно закріпила свій автономний статус - здатність виразити все, не потребуючи будь-якої 
підтримки, це «мистецтво звуків у точному змісті цього слова... незалежне від усіх інших», «прекрасне, всемогутнє», 3 «цілим світом почуттів і відчуттів» (М. Берліоз, цит. за: [19, с. 26]). А музичний інструмент тут виступає як «дивний збіг звукового і зримого та, одночасно, збіг безтілесного (тобто інтонування) і тілесного (знаряддя, конфігурація, рух; утворення системи: «знаряддя - тіло - знаряддя» і т. д.)» [7, с. 127]. Саме в цей період музика починає вимагати «специфічно естетичної уваги, певної цілеспрямованої установки слуху, навички слухати музику «зсередини» музичного твору, як думка й зміст» $[13$, с. 9]. Із цим виходом нового музичного феномена на власне естетичну сутність (позначену пізніше Вагнером) і пов'язана поява в німецькій естетичній науці терміна «абсолютна музика». Відзначимо, що німецька наукова (і у тому числі музично-теоретична) думка в цілому мала в Європі досить значне поширення, відрізнялася стрункістю й систематичністю викладу, повнотою охоплення явищ і музичної практики. При цьому у Німеччині вся проблематика естетичного перебувала під заступництвом систематичної філософії, і такого строгого виховання й подібної теоретичної дисципліни не мала ні естетика Франції, ні естетика Англії [23], ні (додамо) Росії. «Абсолютна музика» стає одним із центральних понять музичної естетики XIX - першої половини XX століття саме завдяки німецькій філософії, у якій термін «абсолютний» мав широкий спектр значень (активно освоювалися поняття абсолютних ідеї, духу, тотожності, розуму і т. ін.). Із зазначеного спектра естетична концепція «абсолютної музики» почерпнула, насамперед, значення «вищого», «ідеального», «самодостатньої сутності».

Філософська ідея абсолюту в інструментальній музиці (на противагу рангової переваги вокальних жанрів у Руссо, Канта, у теорії музичних афектів Дідро й ін.) стверджувалась у теоретичних судженнях (і композиторській творчості) романтиків (Ф. Ліст, Ш. Гуно, Г. Ларош та ін.). Т. Чередниченко вже в XXI столітті вказує, що «абсолютною музикою називали інструментальні твори, вільні від прикладних функцій і не пов'язані із програмністю» [21, с. 27]. Замилування перших романтиків свободою й незалежністю музичного інструменталізму цілком відбивало нові ідеали епохи: інструментальна музика «сама створює собі правила» (Вакенродер), перетворює симфонію в «драму в інструментах» (Вакенродер, Тік), «піднімається над обмеженістю кінцевого, наближаючись до нескінченного» (Гофман) (цит. за: $[19$, c. 27]). 
Вагнер також позначав терміном «абсолютна» музику, яка безпосередньо виражає «нескінченне», виявляє свободу від танцювального й мовного коренів (в емансипації музики від мови вбачав іiї «абсолютність» і Ф. Ніцше). Паралельно в понятійному полі Вагнера з’являються вирази «абсолютна мова звуків», «абсолютна мелодія», «абсолютна гармонія». Слід зазначити, що надалі як під впливом Фейєрбаха, що полемізував з «абсолютною філософією» Гегеля, так і $з$ власних ідей про «художній твір майбутнього» у Вагнера змінюється ставлення до терміна. У 1850-ті роки композитор має на увазі під ним «часткове мистецтво», шо відділилося від свого коріння (слова й танцю в давньогрецькій трагедії) і тому занепале до рівня «порожньої абстракції» [лексикон]. Подібних формально-об'єктивних висновків досягли й засновники терміна. Так, Гофман застосував термін «структура» (цит. за: [19, с. 27]). Однак на піку романтизму ще більш жорстко виявила формальні позиції не німецька, а чесько-австрійська естетична школа в особі Є. Ганслика, Р. Циммермана, О. Гостинського. Перший пропонує повне звільнення від позамузичних асоціацій, звівши зміст та предмет музики до «звучних рухливих форм», другий взагалі заявив, що «сфера музики - звукові уявлення, які не є ні почуттями, ні думками», третій назвав інструментальну музику формальною, безпредметною (цит. за: [19, с. 27]), що, до речі, знайшов неприйнятним товариш Ганслика Й. Брамс.

Але наразі музична естетика «обрала» перший зазначений Вагнером зміст, який уводить до поняття «абстрактної музики» уявлення про вичерпний прояв музичної специфіки, її властиво естетичної сутності.

Починаючи з останньої третини ХІХ століття термін «абсолютна музика» ототожнюється з ідеальною схематикою музичних форм, 3 тектонікою композиції (О. Гостинський, 1877, А. Хальм, 1913) формальна лінія, але також - зі свободою творчості від традиційних структурних шаблонів (Ф. Бузоні, 1906, уважав зразками абсолютної музики прелюдійні та сполучні фрагменти бетховенських творів, оскільки вони позбавлені симетрії та періодичності). К. Дальхауз і Т. Чередниченко співвідносять його позицію з ідеєю А. Шенберга про «музичну прозу» (1950) - вищий прояв специфіки музики.

Основні поняття концепції «Абсолютної музики» підсумовуються в книзі Е. Курта про Брукнера (1925 р.). Курт слушно виділяє два основні значення терміна «абсолютна музика», усталені до його часу 
і актуальні до нашого - 1) автономний інструментальний твір; 2) музичне втілення вищих духовних начал («абсолюту»). Схожі два аспекти поняття демонструє й О. Лосєв: «Під «абсолютною», або «чистою» музикою я розумію музику, позбавлену будь-яких зорових, словесних та інших немузичних образів. Чиста музика - та, яка не містить у собі ніякої сторонньої «програми» і $є$ тільки чиста звучність» [10, с. 14] але з виявленим ликом Божества, зверненим до людини, відзначена серед інших мистецтв як «молитва».

Концепція «абсолютної музики» відокремлює «чисту» музику від програмної («образотворчої»), якій притаманне вираження чого-небудь певного. Однак нерідко визначити межі між абсолютною й програмною музикою уявляється досить складним.Стосовно програмності музики та іiі абсолютного характеру питання можна вважати відкритим у світлі відомого вислову П. Чайковського. Відчуження поняття «абсолютної музики» на теренах вітчизняного музикознавства пояснюється вказаними вище та запереченням у ній «емпірично сприйнятих афектів» та «стихією музичною» російської композиторської школи ХІХ століття.

Взагалі ж, концепція «абсолютної музики» неодноразово зазнавала критики із різноманітних, часто протилежних, позицій. Так Гегель виступав проти неї, вважаючи що «інструментальна музика... не є мистецтвом взагалі». Р. Вагнер кінець кінцем дійшов висновку, що «там, де музика не може йти далі, приходить слово» і тому Дев'яту Симфонію Бетховена він називав «похоронним дзенькотом симфонії». На думку Г. Еггебрехта, концепція «абсолютної музики» недооцінює багатоскладність обладнання музики й механізму ії психологічного впливу, а також ігнорує ту обставину, що навіть найабстрактнішій музичній структурі притаманне змістовне начало. С. Мак-Кларі дещо наслідує П. Чайковського, стверджуючи, що будь-яка музика видно чи ні, містить неявну програму. Кречмар заперечував саме поняття «абсолютної музики» у річищі герменевтичної теорії. В. Карп констатує, що спостерігається постійне коливання між двома полюсами музики - абсолютною та програмною [2]. Це, до речі, не єдина пара полюсів. Так, висока музика має непереборну подвійність: релігійнотрансцендентний зміст, аскетизм, глибина, спокій (Ф. Шлейермахер, О. Лосєв, С. А. Губайдулліна, Г. В. Свиридов) - і почуттєва реальність, пов'язана із щиросердим началом. О. Лосєв вказує на «споглядання» $\mathrm{i}$ «дію», притаманні музиці у ії спрямованості до людини. Усе це ускладнює понятійне поле терміну. 
Втім, поняття «абсолютна музика» відіграло велику роль в історії та теорії музики, затвердивши на теоретичному і практичному рівнях уявлення про те, що саме інструментальне мистецтво є власне музикою. Під формою вираження цього високого мистецтва насамперед розуміють симфонію бетховенського типу, концертний і сонатний інструментальний жанри. На користь «інструментально-музичної парадигми» виступає освітня система музики (від прадавніх часів по сьогодення), яка має на увазі опору на навички інструментальної гри, інструментального інтонування, інструментальний репертуар. У контексті поняття «абсолютна» («чиста», інструментальна, автономна) музика викристалізовувалися й вивчалися явища й поняття, а також корінні властивості музики як виду мистецтва, такі як «позапонятійність», «невербальність», «внутрішня сутність», «чистий зміст», «ідеаційність», «висота», «поетичність», «світ духу», «нескінченність», «нескінченна мелодія», «нескінченна гармонія», «нова естетика числа», «конкретна музика» і т. ін. За К. Дальхаузом, інструментальна музика як позбавлена асоціацій з текстом і програмою вимагає «особливо глибокої уваги, особливо зосередженого вслуховування, вона зрештою заміщає церковну музику на п'єдесталі «святого мистецтва» (цит. за: [21, с. 143]). Тобто музика займає найближчий до Абсолюту ієрархічний щабель і у цьому розумінні законно виступає «абсолютною». Ї̈̈ часом надмірне теоретизування й філософізація виправдані тим, що академічна музика завжди розбудовувалася на тлі формульованих ідей («навчань отців церкви, рішень церковних соборів, указів і постанов світської влади, художніх маніфестів, професійних правил майстрів і т. ін.» [19, с. 202]), чого позбавлений, наприклад, фольклор, де існує лише рівень естетичної організації.

У результаті теоретико-історичного огляду поняття «абсолютна музика» можна дійти висновку про його необоротну спряженість у поняттєво-змістовному полі з поняттями «автономна», «інструментальна», «вокальна», «вокально-інструментальна», «програмна», «прикладна» музика. На наш погляд, ці взаємини складаються у такі пари синонімічного, антонімічного нахилів, а також співвідношення порядку «ціле - часткове». «Плаваючі границі» таких визначень пов'язані з бінарним значенням терміна (Е. Курт - знач. 1 і знач. 2).

1) «часткове / ціле»: «абсолютна 1», «абсолютна 2» / «автономна», «академічна»;

2) «ціле/часткове»: «абсолютна 1», «абсолютна 2» - «інструментальна», «абсолютна 2» - «вокально-інструментальна» академічна; 
3) синонімічні: «абсолютна 1» - «інструментальна академічна»; «абсолютна 2» - «академічна» (інструментальна й вокальноінструментальна);

4) антонімічні: «абсолютна 1» - «вокальна», «вокально-інструментальна»; «абсолютна 1», «абсолютна 2» - «прикладна»; «абсолютна 1», «абсолютна 2» - «програмна» (однак «програмна» через значеннєву рухливість цього терміна - згадаємо П. Чайковського може виступати й у інших співвідношеннях, наприклад, «ціле - часткове»; так, «Пори року» Вівальді не можуть розглядатися як абсолютна музика, оскільки містять велику кількість дескрипторів).

У сучасній музиці зростає роль позамузичних засобів вираження у музичних змістах. Більшість дослідників доходять висновку, що музика представляє багато із значень та змістів, які розуміються у термінах концепції «абсолютної музики».

\section{СПИСОК ЛІТЕРАТУРИ}

1. Абсолютная музыка // Лексикон нонклассики : Художественно-эстетическая культура XX века / Под ред. В. В. Бычкова. - М. : Российская политическая энциклопедия (РОССПЭН), 2003. - 607 с. - (Серия «Summa culturologiae»).

2. Абсолютная музыка // Копирайт () 2013 Вячеслав Карп - Зеркало сцены [Электронный ресурс]. - Режим доступа : http://enc.vkarp.com/2013/01/31

3. Адорно Т. В. Избранное: Социология музыки. - М.; СПб. : Университетская книга, 1998. - 445 с. - (Серия «Книга света»).

4. Асафьев Б. Музыкальная форма как процесс : в 2 кн. Кн. первая и вторая / Б. Асафьев ; ред., вступ. ст. и коммент. Е. М. Орловой. - [2-е изд.]. - Л. : Музыка, 1971. - $376 \mathrm{c}$.

5. Гегель Г. В. Ф. Энциклопедия философских наук : в 3 т. / Г. В. Ф. Гегель. - М., 1977. - Т. 3 : Философия духа. -471 с.

6. Жидков В. Социология искусства : хрестоматия / В. С. Жидков, Т. А. Клявина и др. - М. : Прогресс-Традиция, 2010. - 310 с.

7. Земцовский И. Музыкальный инструмент и музыкальное мышление (к постановке вопроса) / И. Земцовский // Народные музыкальные инструменты и инструментальная музыка : [сб. статей и материалов] : в 2 ч. - М., 1987. - Ч. 1. - С. 125-131.

8. Конен В. Третий пласт: новые массовые жанры в музыке XX века / В. Конен. - М. : Музыка, 1994. - 160 с.

9. Костецкий В. Философия музыки в пространстве теории образования [Электронный ресурс] / Виктор Костецкий // Журнальный клуб Интелрос : «Credo New《 : теоретический журнал. - 2013. - № 1. - Режим доступа : http://www.intelros.ru/readroom/credo_new/k1-2013 
10. Лосев А. Ф. Форма - Стиль - Выражение / А. Ф. Лосев ; сост. ТахоГоди А. А. - М. : Мысль, 1995. - 944 с.

11. Мациевский И. Народная инструментальная музыка как феномен культуры / И. В. Мациевский. - Алматы : Дайк-пресс, 2007. - 520 с.

12. Михайлов А. В. Концепция произведения искусства у Теодора В. Адорно / А. В. Михайлов // Теодор В. Адорно. Избранное : Социология музыки ; пер. М. И. Левина, А. В. Михайлов. - М. ; СПб. : Университетская книга, 1998. - С. 290-293.

13. Михайлов А. Музыка в истории культуры / А. Михайлов. - М., 1998. - 264 c.

14. Неустроев А. О происхождении музыки : Эстетико-психологический очерк / А. А. Неустроев. - СПб., 1892.

15. Ницше Ф. Злая мудрость : Афоризмы и изречения // Сочинения : в 2 т. / Ф. Ницше ; пер. с нем. - М., 1996. - Т. 1. - С. 720-768.

16. Пылаев М. К. Дальхауз об аналитических критериях эстетической оценки музыки (по книге «Анализ и ценностное суждение») / Михаил Евгеньевич Пылаев // Вестник Томского государственного университета. 2012. - Вып. 354. - С. 66-70.

17. Теория современной композиции : [учебное пособие / отв. ред. В. С. Ценова]. - М. : Музыка, 2007. - 624 с.: нот.

18. Флоренский П. Из богословского наследия / П. Флоренский // Богословские труды. - М., 1980. - Т. ХVII. - С. 91-117.

19. Холопова В. Феномен музыки / В. И. Холопова. - М. : Директ-Медиа, 2014. $-378 \mathrm{c}$.

20. Философия : [учеб. для вузов/ под ред. проф. В. Н. Лавриненко, проф. В. П. Ратникова]. - 3-е изд., перераб. и доп. - М. : ЮНИТИДАНА, 2007. - 622 с. - (Серия «Золотой фонд российских учебников»).

21. Чередниченко Т. Тенденции современной западной музыкальной эстетики : [монография] / Т. В. Чередниченко. - М. : Музыка, 1989. - 229 с.

22. Шопенгауэр А. Мир как воля и представление // Шопенгауэр А. О четвертом корне. Мир как воля и представление : Критика кантовской философии : в 2 т. / А. Шопенгауэр. - М. : Наука, 1993. - Т. 1. - С. 268-371.

23. Шушкова О. М. Об эмансипации инструментальной музыки в музыкальной эстетике XVIII века: из истории музыкально-теоретических учений / Ольга Михайловна Шушкова // Гуманитарный вектор. - 2012. - Вып. 3. С. 247-252. - (Серия «Философия, культурология«).

Черноиваненко А. Понятие «абсолютная музыка» в развитии музыкального инструментализма. В статье анализируются понятийно-категориальное поле термина «абсолютная музыка» в развитии академического музыкального инструментализма и его роль в истории и теории музыки. Отмечается значение понятия в утверждении на теоретическом и практическом уровнях представления об инструментальной парадигме «музыки при опоре на гипо- 
тезу И. Земцовского о полигенезисе музыки. Выявляются соотношения понятий «абсолютной», «автономной», «инструментальной», «академической», «прикладной», «программной» музыки.

Ключевые слова: «абсолютная музыка», автономная музыка, музыкальный инструментализм, инструментальная музыка, философия музыки.

Chernoivanenko A. The concept of «absolute music» in the development of musical instrumentalism. The article analyzes the conceptual and categorical field of the term «absolute music» in the development of academic musical instrumentalism and its role in the history and theory of music. The importance of the concept in a statement on the theoretical and practical level idea of the instrumental paradigm «of music by relying on the hypothesis of I. Zemtsovsky polygenesis music are noted. Identified relationship between the concepts of «absolute», «autonomous», «tool», «academic», «application», «program» music.

Key words: «absolute music», an autonomous music, musical instrumentalist, instrumental music, philosophy Music.

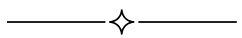

UDC $78.01+785 / .789$

\section{A. Chernoivanenko}

\section{THE CONCEPT OF «ABSOLUTE MUSIC» IN THE DEVELOPMENT OF MUSICAL INSTRUMENTALISM}

This article analyzes the conceptual-categorical field of the term «absolute music» in the development of academic musical instrumentalism and its role in the history and theory of music. The meaning of the concept is emphasized in the affirmation on the theoretical and practical levels of the idea of instrumental paradigm of music with reliance on the hypothesis of I. Zemtsovskyi on the polygenesis of music. Here are revealed the relationships between the concepts of «absolute», «autonomous», «instrumental», «academic», «applied», «program» music.

Key words: «absolute music», autonomous music, musical instrumentalism, instrumental music, philosophy of music

The power of «absolute music» is such that «music remains self-sufficient without any words», - states V. Kholopova [19, p. 192], using the German term of the XIX century, not perceived in the domestic musicology (the Slavic musical thought favored the expression of «pure, non-program instrumental music»). However, the very notion of «absolute music» in its time raised the Beethoven type symphony to a higher level of musical and

(C) Chernoivanenko A., 2014 